\title{
IMPLEMENTATION OF THE ECOSYSTEM APPROACH AS A NECESSARY CONDITION FOR ENSURING THE CONSTITUTIONAL HUMAN RIGHT TO A SAFE ENVIRONMENT FOR LIFE AND HEALTH
}

DOI: 10.36740/WLek202009231

\author{
Yevhenii P. Suietnov \\ YAROSLAV MUDRYI NATIONAL LAW UNIVERSITY, KHARKIV, UKRAINE
}

\begin{abstract}
The aim: Is to study some aspects of the formation of the ecosystem approach, develop on its basis the latest and promising area of scientific research - EcoHealth and determine the legal framework for the implementation of this approach in Ukraine.

Materials and methods: The research is based on international legal documents, statistical reports and information of the WH0, practice of the ECHR, constitutional acts of foreign countries, legislation of Ukraine, works of scientists on ecology, medicine, environmental and medical law. For achievement of reliable and objective results general philosophical (dialectical), general scientific (historical, analysis and synthesis, analogy) and special (comparatively-legal, interpretation of legal norms) methods of scientific knowledge were used.

Conclusions: A necessary condition for ensuring the constitutional human right to a safe (favorable, benevolent, healthy, etc.) environment for life and health and, consequently, the right to life and health, is the implementation of an ecosystem approach into national strategies and legislation of different countries, including Ukraine. The development of this approach at the international level has led to the emergence of a new area of scientific research - EcoHealth, which studies how changes in the Earth's ecosystems affect human health. In Ukraine, the issue of implementing an ecosystem approach to health is not widespread in the scientific literature yet, but this trend is clearly visible in environmental legislation.
\end{abstract}

KEY WORDS: the right to life and health, the right to a safe environment for life and health, the right to a favorable environment, ecosystem, ecosystem approach

Wiad Lek. 2020;73(9 p. II):2062-2067

\section{INTRODUCTION}

Human life and health depend on the quality and safety of the environment in which they live. According to WHO, roughly 12.6 million people die every year from environment, which is $23 \%$ of all deaths in the world [1]. Among the environmental risks are air, water and soil pollution, ultraviolet and ionizing radiation, climate change, hazardous waste, chemical and biological substances, etc., while the main deadly diseases caused by contaminated ones are such diseases as stroke (2.5 million), ischaemic heart disease (2.3 million), unintentional injuries (1.7 million), cancer (1.7 million) and chronic respiratory diseases (1.4 million) [2].

Environmental risk factors are also recognized as a global cause of child mortality, as they kill 1.7 million children under the age of five each year, representing more than a quarter (26\%) of deaths at that age [3]. "A healthy environment underpins a healthy population," says Dr. Margaret Chan, WHO Director-General. "If countries do not take actions to make environments where people live and work healthy, millions will continue to become ill and die too young." [4]. Therefore, it is obvious that the right of every person to life and health is inextricably linked to right to a safe and healthy environment, the adequate ensuring and protection of which is an urgent necessity of today.
In accordance with Article 3 of the Constitution of Ukraine, human life and health are recognized as the highest social value. This constitutional norm is specified in other articles of the Fundamental Law of Ukraine, in particular in Article 27, under which every person has the inalienable right to life, the protection of which is the duty of the State, and Article 49, which proclaims everyone's right to health protection, medical care and medical insurance. Regarding the right to a safe environment, it is enshrined in Article 50, according to which everyone has the right to an environment that is safe for life and health, and to compensation for damages inflicted through the violation of this right.

Unlike Ukrainian legislation, which uses the term "the right to a safe environment", the international legal documents, acts of the EU and the legislation of other countries enshrine the right to "a favorable environment", "a benevolent environment", "a healthy environment", etc. For example, the Constitution of the Republic of Latvia declares that "the State shall protect the right of everyone to live in a benevolent environment" (Article 115); according to the constitutions of Hungary and Belgium, everyone has "the right to a healthy environment" (Article XXI and 
Article 23, respectively); the Constitution of the Republic of Bulgaria admits for everyone "the right to a healthy and favorable environment" (Article 55).

The human right to a safe (favorable, benevolent, healthy, etc.) environment is also ensured by the norms of the Convention for the Protection of Human Rights and Fundamental Freedoms (1950), better known as the European Convention on Human Rights. Although the Convention does not have a particular article on this right, however, according to the practice of the European Court of Human Rights, in case a person applies for protection of the violated right, the ECHR considers and decides the case, guided by Article 8 of the Convention, which proclaims that "everyone has the right to respect for his private and family life, his home and his correspondence". It is on the basis of this Article that the ECHR issued a number of decisions in cases both with regard to foreign states and Ukraine (in particular, "Lopez Ostra v. Spain", "Giacomelli v. Italy", "Hatton and Others v. the United Kingdom", "Fadeyeva v. Russia", "Dubetska and Others v. Ukraine", "Grimkovskaya v. Ukraine", etc.).

An analysis of the main documents on the protection of environment, life and health gives reason to assert that the human right to a safe (favorable, benevolent, healthy, etc.) environment for life and health and, consequently, the human right to life and health is inevitably linked to the conservation and restoration of natural ecosystems, which should be carried through the implementation of an ecosystem approach.

\section{THE AIM}

The aim of the research is to study some aspects of the formation of the ecosystem approach, develop on its basis the latest and promising area of scientific research - EcoHealth and determine the legal framework for the implementation of this approach in Ukraine.

\section{MATERIALS AND METHODS}

The research is based on international legal documents, statistical reports and information of the WHO, practice of the ECHR, constitutional acts of foreign countries, legislation of Ukraine, works of scientists on ecology, medicine, environmental and medical law. For achievement of reliable and objective results general philosophical (dialectical), general scientific (historical, analysis and synthesis, analogy) and special (comparatively-legal, interpretation of legal norms) methods of scientific knowledge were used.

\section{REVIEW AND DISCUSSION}

The central category of the ecosystem approach is the eco-

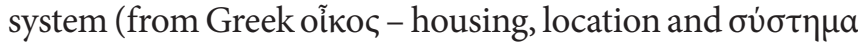
- combination, association) - a set of living organisms and the conditions of their existence, which are in a natural interconnection with each other and form a system of mutually-conditioned biotic and abiotic phenomena and processes. It is well known that the term "ecosystem" was introduced into scientific use by the English botanist and a pioneer in the science of ecology A.G. Tansley, who wrote in the book "The use and abuse of vegetational concepts and terms" (1935) about the impossibility of separating organisms from their special environment, with which they form one physical system. These ecosystems, as we may call them, are the basic units of nature on the face of the earth and they are of the most various kinds and sizes [5].

Later in the scientific literature, other definitions of the ecosystem were developed and justified the dependence of human life on the stable functioning of ecosystems. According to E.P. Odum, considered the father of modern ecology, an ecosystem is any entity or natural unit that includes living and nonliving parts interacting to produce a stable system in which the exchange of materials between the living and the nonliving parts follows circular paths [6]. In another publication the scientist writes that the ecosystem is the main functional unit of ecology, as it includes both organisms (biotic communities) and the abiotic environment, with each of these parts influencing the other and both necessary to sustain life as it exists on Earth. And emphasizing the importance of careful study and conservation of ecosystems, he notes that approaches to the study of ecosystems must be translated into an action program if people are to survive the current environmental crisis that they themselves have created [7].

Modern environmental scientists, including V.I. Danilov-Danilyan, V.I. Losev and I.E. Reyf, speak out on this problem no less eloquently. It is significant, they write, that not only people who are far from science, but also many environmentalists have not yet realized what is the central point of global environmental changes that have occurred over historical time, and especially over the past 50-100 years, as a result of environmentally destructive economic development and unbridled demographic growth. This is not the pollution of the environment, which affects the majority of the world's population. And it is not climate warming, whose connection with the greenhouse effect is still being questioned by some researchers. The main environmental outcome of human economic activity is the destruction of natural ecosystems in vast land areas as well as in the water areas of semi-enclosed seas and the coastal oceanic zone. It is the sharp weakening of the environment-forming and stabilizing functions of biota on large territories that threatens the biosphere with the most catastrophic consequences. And only reliance on natural forces, on the natural potential of living biota can, perhaps, prevent the worst option for further development - demographic collapse, population decline, erosion of the foundations of modern civilization, etc. In general, the destruction or deformation of natural ecosystems as a result of human activities is undoubtedly the most important and essential aspect of the global environmental crisis [8].

Considering the functions of ecosystems in nature and their importance for maintaining its favorable condition, the problem of preserving and restoring ecosystems in order to ensure a safe and sustainable future for mankind 
has become extremely important. It is from these considerations that in international law a strategy for integrated management of natural resources was developed, which is called the "ecosystem approach".

Some aspects of the ecosystem approach, in particular those that indicate the dependence of human life and health and its right to a safe environment on the proper functioning of ecosystems, are enshrined in leading international legal instruments. In the 1st principle of the Declaration of the United Nations Conference on the $\mathrm{Hu}$ man Environment, adopted at the Stockholm Conference in 1972, it is noted that man has the fundamental right to adequate conditions of life, in an environment of a quality that permits a life of dignity and well-being. And in the 2 nd and 6th principles it is stated that representative samples of natural ecosystems must be safeguarded for the benefit of present and future generations through careful planning or management, and negative impact on the environment must be halted in order to ensure that serious or irreversible damage is not inflicted upon ecosystems.

The Rio Declaration on Environment and Development, which was adopted at the Rio de Janeiro Earth Summit in 1992, among the main principles also outlines the human right to a healthy and productive life in harmony with nature (Principle 1) and the need for States to cooperate in a spirit of global partnership to conserve, protect and restore the health and integrity of the Earth's ecosystem (Principle 7). And adopted at that Conference Agenda 21 begins by saying that humanity is confronted with different problems including the continuing deterioration of the ecosystems on which we depend for our well-being. However, integration of environment and development concerns and greater attention to them will lead to the fulfillment of basic needs, improved living standards for all, better protected and managed ecosystems and a safer, more prosperous future (Preamble).

Such statements is enshrined in the Plan of Implementation of the World Summit on Sustainable Development (Earth Summit 2002, Johannesburg), which states that human activities are having an increasing impact on the integrity of ecosystems that provide essential resources and services for human well-being and economic activities. In this regard, to reverse the current trend in natural resource degradation as soon as possible, it is necessary to implement strategies which should include targets adopted at the national and regional levels to protect ecosystems and to achieve integrated management of land, water and living resources (Paragraph 24). And the document "The Future We Want" adopted at the United Nations Conference on Sustainable Development (Earth Summit 2012, Rio de Janeiro) declares that sustainable development can be achieved by promoting the integrated and sustainable management of natural resources and ecosystems that supports economic, social and human development while facilitating ecosystem conservation, regeneration and restoration and resilience in the face of new and emerging challenges (Paragraph 4).

The dependence of human life and health on sustainable ecosystem functioning is also well documented in the report "Ecosystems and Human Well-being: Health Synthesis", which was prepared as part of the Millennium Ecosystem Assessment (MA). This report indicates that in a fundamental sense, ecosystems are the planet's life-support systems - for the human species and all other forms of life. The needs of the human organism for food, water, clean air, shelter and relative climatic constancy are basic and unalterable. That is, ecosystems are essential to human well-being and especially to human health - defined by the World Health Organization as a state of complete physical, mental and social well-being. Those who live in materially comfortable, urban environments commonly take for granted ecosystem services to health. They assume that good health derives from prudent consumer choices and behaviours, with access to good health care services. But this ignores the role of the natural environment: of the array of ecosystems that allow people to enjoy good health, social organization, economic activity, a built environment and life itself (1.1 Introduction) [9].

The importance of conservation and restoration of ecosystems to human life and health is directly derived from WHO documents. As indicated in the document of the WHO Regional Office for Europe "Improving environment and health in the context of Health 2020 and the 2030 Agenda for Sustainable Development: outcomes of the Sixth Ministerial Conference on Environment and Health", there is a growing body of evidence crucial to understanding emerging and future challenges that shows the health of humanity and the health of the environment and the planet are intrinsically linked and that human activity is threatening to destabilize the Earth's key life-support systems. Changes to the Earth's natural systems pose a substantial threat to human health, well-being and security, and will become increasingly severe over time if no action is taken (Paragraph 4) [10].

However, the most effectively issues of international legal protection of ecosystems and implementation of the ecosystem approach are being developed under the Convention on Biological Diversity of June 5, 1992 [11], the objectives of which are the conservation of biological diversity, the sustainable use of its components and the fair and equitable sharing of the benefits arising out of the utilization of genetic resources (Article 1). The Convention defines the "ecosystem" as a dynamic complex of plant, animal and micro-organism communities and their non-living environment interacting as a functional unit (Article 2), and establishes the obligations to preserve and restore natural ecosystems. In particular, each Contracting Party shall: promote the protection of ecosystems; rehabilitate and restore degraded ecosystems; prevent the introduction of, control or eradicate those alien species which threaten ecosystems, etc. (Paragraphs "d", "f" and "h" of Article 8).

The text of the Convention doesn't specify an ecosystem approach, but there are a number of decisions of the meetings of its governing body, the Conference of the Parties (COP), which set out the framework for the ecosystem approach and its relation to a safe and healthy environment. The First Meeting of the COP, held in Nassau (Bahamas, 
1994), recognized that the planet's essential goods, ecological functions and services depend on the variety and variability of ecosystems. If humanity is to have a future on this earth, biological diversity must be conserved, because its depletion causes threats to ecosystems that are vital for the sustenance of human societies in all countries (Paragraph 1 of Annex to Decision I/8).

Of particular importance to the development of the ecosystem approach was the Fifth Meeting of the COP in Nairobi (Kenya, 2000), which adopted Decision V/6 "Ecosystem Approach", that contains a description of this approach (Section A), its 12 principles (Section B) and operational guidance for their application (Section C) [12]. According to Section A, the ecosystem approach is a strategy for the integrated management of land, water and living resources that promotes conservation and sustainable use in an equitable way. An ecosystem approach is based on the application of appropriate scientific methodologies focused on levels of biological organization, which encompass the essential structure, processes, functions and interactions among organisms and environment. It recognizes that humans, with their cultural diversity, are an integral component of many ecosystems.

No less important for the development of the ecosystem approach were other meetings of the COP, in particular the Sixth (The Hague, Netherlands, 2002) and the Seventh (Kuala Lumpur, Malaysia, 2004), where the inclusion of this approach in the thematic programs of the Convention at the local, national and regional levels and the need for its implementation in national strategies and legislation of different countries were discussed.

The active development of the ecosystem approach at the international level has led to the emergence of a new area of scientific research - EcoHealth, which explores how changes in the Earth's ecosystems affect human health. According to G. Forget and J. Lebel, the ecosystem approach to human health is a new, holistic approach that flows from the metaphor of the "healthy ecosystem" - it places human beings at the center of considerations about development, while seeking to ensure the durability of the ecosystem of which they are an integral part. There can be no sustainable development unless interventions take into account both the well-being of human beings and the survival of the ecosystem. This research approach is particularly appropriate for developing countries, because it is much better able to accommodate the complexity of the systems concerned. It is not, however, an intuitive approach for researchers, and it requires a considerable philosophical adjustment. Nevertheless, this new approach is now coming into its own, especially as the impact of environmental changes on human health becomes increasingly evident [13].

The views of $\mathrm{N}$. Ole Nielsen in this context are interesting too. He writes that in the course of history the human social system has become so influential and so entangled in the natural or ecological system that society can no longer act without more regard for nature. Human social systems have both local and global impacts that can impair the quality of life, predispose to disease, and even threaten life support systems. It has become essential to try to understand our world as a complex socio-ecological ecosystem and take such steps as are necessary to manage human affairs in ways that promote the health not only of people but also of the planet. Reductionist science by itself cannot deal with the complexity of this task. The ecosystem approach is one means to this end since it recognizes the interconnectedness of biotic and abiotic elements of the environment and effectively derives from a management perspective. Simply stated, managing for human health must be embedded in the wider pursuit of ecosystem health [14].

A significant contribution to the development of this issue was made by D.F. Charron, according to whom ecosystem approaches to health (or ecohealth research) formally connect ideas of environmental and social determinants of health with those of ecology and systems thinking in an action-research framework applied mostly within a context of social and economic development. Ecosystem approaches to health focus on the interactions between the ecological and socio-economic dimensions of a given situation, and their influence on human health, as well as how people use or impact ecosystems, the implications for the quality of ecosystems, the provision of ecosystem services, and sustainability. In the course of his research, the scientist forms six principles of an ecosystem approach to health (systems thinking; transdisciplinary research; participation; sustainability; gender and social equity; knowledge to action) and provides guidance on how to put these principles into practice [15].

Issues related to the study of the EcoHealth are of particular relevance to scientists in different countries today. Thus, Ziad D. Al-Ghazawi touched on the problem of the ecosystem approach to human health in two villages of the North Jordan Valley [16]. T. Asakura et al. studied this approach to health as a promising strategy in international development on the example of Japan and Laos [17]. H. Nguyen-Viet and T. Thi Tuyet Hanh identified some possibilities and problems of its application in environmental health research in Vietnam [18].

A separate direction is the study of specific diseases. Thus, R. Bazzani, L. Noronha and A. Sanchez focused their attention on the study of the use of an ecosystem approach to health for the prevention of communicable diseases [19], A. Alonso Aguirre et al. considered this issue regarding parasitic and vector-borne diseases [20], and G.N. Bratman et al. emphasized on mental diseases [21]. There are scientific publications that combine the territorial principle with specific diseases (for example, N. Arya et al. studied the expediency of implementing an ecosystem approach to public health on the lessons from two infectious disease outbreaks in Canada [22]).

The popularity of this issue led to the creation in 2010 an organization EcoHealth Alliance formed with the merger of two highly respected organizations, Wildlife Trust and the Consortium for Conservation Medicine. Building on over $45+$ years of groundbreaking science, EcoHealth Alliance is a global environmental health nonprofit organization dedicated to protecting wildlife and public health from 
the emergence of disease. The urgent concern for wildlife conservation and the overall health of our planet has led EcoHealth Alliance to become an environmental science and public health leader working to prevent pandemics in global hotspot regions across the globe and to promote conservation [23]. In addition, it should be noted that the EcoHealth Alliance issues the international journal "EcoHealth" which aims are to advance research, practice, and knowledge integration at the interface of ecology and health by publishing high quality research and review articles that address and profile new ideas, developments, and programs. Papers address integrated ecology and health challenges arising in public health, human and veterinary medicine, conservation and ecosystem management, rural and urban development and planning, and other fields that address the social-ecological context of health.

As for Ukraine, unfortunately, the issue of implementing an ecosystem approach to health hasn't yet become widespread in the scientific literature. At the same time, we can see positive changes in this direction, as there are some scientific articles, monographs and other publications, which advocate the implementation of a holistic (holistic) approach to health. Thus, in the monograph called "General Theory of Health and Healthcare" Yu.D. Boychuk writes that the holistic approach allows us to determine the hierarchy of levels in nature as a single holistic system, one of the elements of which is human health. In this consideration, the health problem reveals a connection with the social-ecological system as a higher-level meta-integrity. As a matter of fact, the health of an individual, ethnos, humanity are in their interconnections, on the one hand, as a condition, and on the other, as a result of the sustainable development of social-ecological system. The holistic approach makes it possible to consider all aspects of the cosmoplanetary and biopsychosociocultural nature of human. It gives an opportunity to consider health as a system-forming quality, a result of interaction of biosphere, biology and ecology of a human, his lifestyle and purposeful self-establishment on health. Characteristics of health of ethnic groups and humanity as a whole should be considered taking into account influence of factors of social evolution, history of ethnic groups and humanity. So, the holistic approach to health causes the necessity to consider the human being as a part of social-ecological system, which actively influences it and at the same time experiences the reverse action from its side. In conditions of global ecological and social-economic crisis, application of holistic approach to understanding human nature and mechanisms of human health contributes to formation of self-preservation philosophy as a worldview platform for prevention of degradation of biosphere and human [24].

More clearly and consistently, the issue of implementing an ecosystem approach in the context of ensuring the human right to a safe environment for life and health can be traced to leading environmental regulatory acts. In particular, on February 28, 2019 the Law of Ukraine "On the Basic Principles (Strategy) of the State Environmental Policy of Ukraine for the Period until 2030" was adopted [25], which at least ten subsequent years will have the status of a "leading pointer" on the way from overcoming the current environmental crisis to building a state based on the best international and European environmental standards. This Law pays considerable attention to the need to preserve and restore ecosystems. It is stated that one of the main tasks for ensuring sustainable development of natural resource potential (Goal 2) is to improve the condition of affected ecosystems, and the tasks to reduce environmental risks to minimize their impact on ecosystems, socio-economic development and public health (Goal 4) are reducing anthropogenic impacts on ecosystems and preventing the spread of invasive species and controlling their appearance in natural ecosystems.

But most importantly, in accordance with this Law, the implementation of an ecosystem approach is recognized as a necessary condition not only for stabilizing and improving the environment as a whole, but also for ensuring the human right to a safe environment. Section II, which points out the purpose, foundations, principles and tools of environmental policy, states that its goal is to achieve a good environment through the implementation an ecosystem approach to all areas of socio-economic development of the state to ensure the constitutional right of every citizen to a clean and safe environment, the introduction of balanced natural resource use, as well as the conservation and restoration of ecosystems. The consolidation of this provision is an extremely important achievement, which requires further thorough scientific development and practical implementation.

\section{CONCLUSIONS}

Thus, it can be concluded that a necessary condition for ensuring the constitutional human right to a safe (favorable, benevolent, healthy, etc.) environment for life and health and, consequently, the right to life and health, is the implementation of an ecosystem approach into national strategies and legislation of different countries, including Ukraine. The development of this approach at the international level has led to the emergence of a new area of scientific research - EcoHealth, which studies how changes in the Earth's ecosystems affect human health. In Ukraine, the issue of implementing an ecosystem approach to health is not widespread in the scientific literature yet. However, this trend is clearly visible in leading environmental regulatory act - the Law "On the Basic Principles (Strategy) of the State Environmental Policy of Ukraine for the Period until 2030".

\section{REFERENCES}

1. Prüss-Üstün A., Wolf J., Corvalán C. et al. Preventing disease through healthy environments: a global assessment of the burden of disease from environmental risks. Geneva: WH0. 2016:147.

2. World Health Organization (WHO). Infographic: Environmental impacts on health. What is the big picture? WHO. 2017. https://www.who. int/quantifying_ehimpacts/publications/PHE-prevention-diseasesinfographic-EN.pdf 
3. World Health Organization (WHO). Infographic: Protecting the children from the environment. [Internet]. WH0. 2017. https://www.who.int/ ceh/publications/ceh-Infographics-2017-english.pdf

4. World Health Organization (WHO). An estimated 12.6 million deaths each year are attributable to unhealthy environments. WH0. 2016. https://www.who.int/news-room/detail/15-03-2016-an-estimated12-6-million-deaths-each-year-are-attributable-to-unhealthyenvironments

5. Tansley A.G. The use and abuse of vegetational concepts and terms. Ecology. 1935; 16(3):284-307.

6. Odum E.P. Fundamentals of ecology. Philadelphia: W.B. Saunders Company. 1953: 384.

7. Odum E.P. Fundamentals of ecology. Third edition. PhiladelphiaLondon-Toronto: W.B. Saunders Company. 1971: 574.

8. Danilov-Danil'jan V.I., Losev K.S., Rejf I.E. Pered glavnym vyzovom civilizacii: Vzgljad iz Rossii [Before the main challenge of civilization: A view from Russia]. INFRA-M; 2005:224. (in Russian).

9. Corvalan C., Hales S., McMichael A., Bulter C. Đet al Ecosystems and human well-being: health synthesis: a report of the Millennium Ecosystem Assessment. WH0. 2005: 53.

10. World Health Organization Regional Office for Europe (WHO Europe). Improving environment and health in the context of Health 2020 and the 2030 Agenda for Sustainable Development: outcomes of the Sixth Ministerial Conference on Environment and Health (Budapest, Hungary, 11-14 September 2017). http://www.euro.who.int/_data/assets/ pdf_file/0009/345069/67wd15e_0utcome0strava_170705.pdf

11. Convention on Biological Diversity 1992. https://www.cbd.int/ convention/text/

12. Decisions adopted by the Conference of the Parties to the Convention on Biological Diversity at its Fifth Meeting (Nairobi, 15-26 May 2000). DecisionV/6: Ecosystem Approach, UNEP/CBD/COP/5/23 (22 June 2000). https://www.cbd.int/doc/decisions/cop-05/full/cop-05-dec-en.pdf

13. Forget G., Label J. An ecosystem approach to human health. International journal of occupational and environmental health. 2001; 7(2):3-38.

14. Nielsen N.0. Ecosystem approaches to human health. Cadernos de Saúde Pública. 2001; 17:69-75. doi: 10.1590/S0102-311X2001000700015

15. Charron D.F. Ecohealth: Origins and Approach. In: Charron D.F., ed. Ecohealth Research in Practice. Innovative Applications of an Ecosystem Approach to Health. International Development Research Centre 0ttawa, Cairo, Dakar, Montevideo, Nairobi, New Delhi, Singapore; 2012, p. 1-30. doi: 10.1007/978-1-4614-0517-7

16. Al-Ghazawi Z.D. Ecosystem approach to human health in two villages of the North Jordan Valley: scoping the problems. EcoHealth. 2004; 1(2):97-108. doi: 10.1007/s10393-004-0089-3

17. Asakura T., Mallee H., Tomokawa S. et al. The ecosystem approach to health is a promising strategy in international development: lessons from Japan and Laos. Globalization and Health. 2015; 11:3. doi: 10.1186/ s12992-015-0093-0

18. Nguyen-Viet H., Tuyet-Hanh T.T. Ecosystem approach to health (Ecohealth): Theory and practices in environmental health research in Vietnam. Hanoi, Vietnam: Medical Publishing House. 2016. https:// cgspace.cgiar.org/handle/10568/77089
19. Bazzani R., Noronha L., Sánchez A. An Ecosystem Approach to Human Health: building a transdisciplinary and participatory research framework for the prevention of communicable diseases. 2004. http:// www.iai.int/admin/site/sites/default/files/uploads/Ecohealth_and_ Communicable_Diseases.pdf

20. Aguirre A.A., Basu N., Kahn L.H. et al. Transdisciplinary and socialecological health frameworks - Novel approaches to emerging parasitic and vector-borne diseases. Parasite Epidemiology and Control. 2019; 4:e00084. doi: 10.1016/j.parepi.2019.e00084 2019

21. Bratman G.N., Anderson C.B., Berman M.G. et al. Nature and mental health: An ecosystem service perspective. Science Advances. 2019; 5(7):eaax0903. doi: 10.1126/sciadv.aax0903

22. Arya N., Howard J., Isaacs S. et al. Time for an ecosystem approach to public health? Lessons from two infectious disease outbreaks in Canada. Global Public Health. 2009; 4(1):31-49. doi: 10.1080/17441690701438128

23. EcoHealth Alliance. https://www.ecohealthalliance.org/about

24. Boichuk Yu.D., ed. Zahalna teoriia zdorov'ia ta zdorov'iazberezhennia [General Theory of Health and Healthcare]. Kharkiv: Rozhko S.H.. 2017:488. (in Ukrainian).

25. Pro Osnovnizasady (stratehiiu) derzhavnoi ekolohichnoi polityky Ukrainy na period do 2030 roku: Zakon Ukrainy vid 28.02.2019 r. № 2697-VIII [On the Basic Principles (Strategy) of the State Environmental Policy of Ukraine for the Period until 2030: Law of Ukraine No. 2697-VIII of February 28, 2019]. (In Ukrainian).

\section{ORCID and contributionship:}

Yevhenii P. Suietnov: 0000-0002-4094-444X A, B, C, D, E, F

\section{Conflict of interest:}

The Author declare no conflict of interest.

\section{CORRESPONDING AUTHOR Yevhenii P. Suietnov}

Yaroslav Mudryi National Law University

77 Pushkinska st., 61024, Kharkiv, Ukraine

tel.: +380938506200

e-mail: evgeny-suetnov@ukr.net

Received: 11.04 .2020

Accepted: 23.07 .2020

A - Work concept and design, B - Data collection and analysis, C - Responsibility for statistical analysis, D-Writing the article, $\mathbf{E}$-Critical review, $\mathbf{F}$ - Final approval of the article 